\title{
Olive mill wastewater treatment using infiltration percolation in column followed by aerobic biological treatment
}

\author{
A. Benamar ${ }^{1} \cdot$ F. Z. Mahjoubi ${ }^{1,2} \cdot$ N. Barka ${ }^{2} \cdot$ F. Kzaiber $^{3} \cdot$ K. Boutoial $^{3} \cdot$ Gomaa A. M. Ali $^{4} \cdot$ A. Oussama $^{1}$
}

Received: 6 February 2020 / Accepted: 10 March 2020 / Published online: 14 March 2020

(c) Springer Nature Switzerland AG 2020

\begin{abstract}
This work aims to treat olive mill wastewater (OMWW) by infiltration percolation in different columns containing filtration sand, granular activated carbon, and lime, and thus followed by biological treatment using the soil microorganisms to the treatment that will give the best results. The optimum removal efficiency was obtained using granular activated carbon column mixed with $15 \%$ of lime with percentages removal of $39.33,60.28,53.17$ and $88.74 \%$ for biological oxygen demand (BOD5), chemical oxygen demand (COD), polyphenols and suspended matter respectively. Aerobic treatment 30 days of OMWW obtained from the column of activated carbon mixed with $15 \%$ of lime, neutralized and diluted 15 times with distilled water was investigated. The results showed a significant percentage reduction of $79.78,69.43$, and $60.67 \%$, respectively, for BOD5, COD, and polyphenols. The global removal percentages after the two successive treatments were $87.86 \%$ for COD, $87.39 \%$ for BOD5 and $81.59 \%$ for polyphenols compounds. Fourier Transformed Infrared spectroscopy analysis of crude OMWW, infiltrated percolated and biologically treated, showed a difference between the spectra that manifests by the reduction of the spectrum intensity bands after each treatment stage, which confirmed the analytical results. Soil microorganisms have shown their biodegradation efficiency of organic matter and polyphenols of these much-polluted effluents under aerobic conditions. The results indicated that the pretreatment of raw olive mill wastewater could be realized before biological treatment to obtain a satisfactory reduction.
\end{abstract}

Keywords Olive mill wastewater · Infiltration percolation · Biological treatment $\cdot$ Fourier transformed infrared spectroscopy (FTIR)

\section{Introduction}

Olive mill wastewater (OMWW) is smelly wastewater that poses severe problems for aquatic and environmental systems. In the Mediterranean regions which produce about $97 \%$ of the worldwide olive oils, OMWW production was estimated at 30 million $\mathrm{m}^{3}$ per year [1]. Morocco is among the Mediterranean countries most producing olive oil. This industry, so beneficial for the national economy, generates liquid discharges pollution to the environment. The quantities of OMWW generated in Morocco (the sixth largest producer of olive oil in the world) are estimated at more than $250,000 \mathrm{~m}^{3}$ per year [2]. The principal waste produced by the olive industry is olive mill wastewater (OMWW). Olive oil extraction by different technics generates a significant amount of both solid (olive pomace) and liquid by-products (olive mill wastewater) during olive harvesting season, generally from November to March [3].

The extraction method, climatic conditions, olive cultivar and characteristics of the fruit are the principal

F. Z. Mahjoubi, mahjoubi.fatimazahra@gmail.com | ${ }^{1}$ Equipe de Spectro - Chimiométrie Appliquée et Environnement, Université Sultan Moulay Slimane, FST Béni Mellal, B.P. 523, Béni Mellal, Morocco. ${ }^{2}$ Research Group in Environmental Sciences and Applied Materials (SEMA), University Sultan Moulay Slimane, FP Khouribga, B.P. 145, 25000 Khouribga, Morocco. ${ }^{3}$ Ecole Supérieure de Technologie de Beni Mellal, Laboratoire d'Ingénierie et Technologies Appliquées (LITA), Université sultan Moulay Slimane, Béni Mellal, Morocco. ${ }^{4}$ Chemistry Department, Faculty of Science, Al-Azhar University, Assiut 71524, Egypt. 
responsible factors of OMWW characteristic differences [4]. The high-level quantities of OMWW (ranging from 0.5 to $1.5 \mathrm{~m}^{3}$ per ton of olives) arising from olive oil extraction, has increased attention in treating or reducing pollution caused by this liquid by-product [5]. OMWW were contained of water (83-92\%), organic compounds (4-16\%), and inorganic chemicals (1-2\%) [6], furthermore, it constitutes about 100-150 times greater contaminants than domestic wastewater [7] with high content of chemical oxygen demand (COD) up to $220 \mathrm{~g} / \mathrm{L}$ and important biochemical oxygen demand (BOD) up to $100 \mathrm{~g} / \mathrm{L}$ [5]. This shows the high oxygen demand for the complete oxidation of the organic matter contained in these effluents, which reflects their very high polluting powers.

Olive polyphenols during extraction processes of oil are partitioned between the water phase and the oil phase; however, the major fraction is missing in the wastewater from the fact that they are water-soluble substrates of high polarity, only $2 \%$ is passed in the oil, $53 \%$ and $45 \%$ approximately of the rest is lost in the olive mill wastewater and the pomace respectively [8]. The polyphenols content in OMWW varies from 5 to $25 \mathrm{~g} / \mathrm{L}$ [9]. Indeed, olive mill wastewaters are not easily biodegradable due to their high chemical and biochemical oxygen demand, their high contents in phenolic compounds, high ratio $\mathrm{C} / \mathrm{N}$ and low $\mathrm{pH}$, leading consequently to major dangers to environment system related to the contamination of soil, pollution of water bodies, obstruction and inhibition of plants growing, leaks to the groundwater, inhibition of auto purification processes, as well as phytotoxic impacts to aquatic fauna and to ecological equilibria and powerful odor nuisance have been reported so far [10, 11].

Discharge of untreated wastewater to the environment may not only cause adverse effects to human beings and the ecosystem, but it may also cause difficulty during conventional water treatment. To ensure that clean and safe water is supplied to the community, conventional water treatment processes are employed to reduce the level of contaminants found in water. Water treatment is a process of reducing the level of contaminants found in water to acceptable levels which are not harmful to living organisms and their environment [12-14]. Conventional water treatment methods are employed by water treatment utilities to reduce the level of contaminants found in water and supply clean water which is safe for potable use and disposal to the environment [15].

The high toxic effect of OMWW is principally due to the presence of high concentrations of total phenolic compounds (TPCs) and residual fatty matter. Many of phenolic compounds (PCs) are toxic to animal and vegetable organisms, they can be persistent and bioaccumulative, especially chlorinated forms might be dangerous to human health [16].
The treatment of olive mill wastewater has been investigated by many researchers, using several treatment techniques to remove contaminants from this wastewater. Among these processes, there are lagooning or natural evaporation and thermal concentration [17], composting [18], treatments with clay [19], coagulation-flocculation [20], electrocoagulation [21], and Fenton's reaction [22]. Some authors such as Scoma et al. [23] studied the use of the Physico-chemical and biological approach as a technique for the recovery and treatment of OMWW. Coupling physicochemical and biological processes have received a lot of attention in recent years as a promising treatment alternative for effluents that are too toxic to treat biologically. All of these methods proposed by these several researchers are not yet led to completely satisfactory results in treatment of this black liquid, for this reason, our work is aimed at investigating the efficiency and feasibility of olive mill wastewater treatment by infiltration percolation in column followed by biological treatment using soil microorganisms under aerobic conditions in order to evaluate the possibility of reusing Olive Mill Wastewater. The capacity of removing the phenolic compounds, $\mathrm{BOD}_{5}$, COD and suspended matter will be evaluated.

\section{Materials and methods}

\subsection{Sampling and origin of olive mill wastewater}

Olive mill wastewater (OMWW) in this study was collected in January 2018 from an olive extraction plant that used a traditional process located in Beni Mellal area (Morocco) (Fig. 1). No chemical additives were used during olive oil production. OMWW was transported in $5 \mathrm{~L}$ bottles and stored in a dark place at an approximate temperature of $4{ }^{\circ} \mathrm{C}$ until required for analysis.

\subsection{Analytical methods}

The OMWW was characterized by the following parameters: Potential hydrogen $(\mathrm{pH})$, electrical conductivity $(E C)$, chemical oxygen demand (COD), biological oxygen demand $\left(\mathrm{BOD}_{5}\right)$, suspended matter $(\mathrm{SM})$ and polyphenols. $E C$ was determined by a conductivimeter ADWA AD3000, $\mathrm{pH}$ was measured by a $\mathrm{pH}$ meter HANNA HI2211, SM and $\mathrm{COD}$ were quantified according to Rejesek [24], $\mathrm{BOD}_{5}$, it was measured according to Rodier [25], and the polyphenols were evaluated using Folin-Ciocalteu assay as described by Atanassovaa et al. [26]. The different physicochemical parameters in our work are measured before and after each treatment of OMWW to show the difference in load, decrease or increase of each parameter studied and the effectiveness of the treatment used. The characteristics 


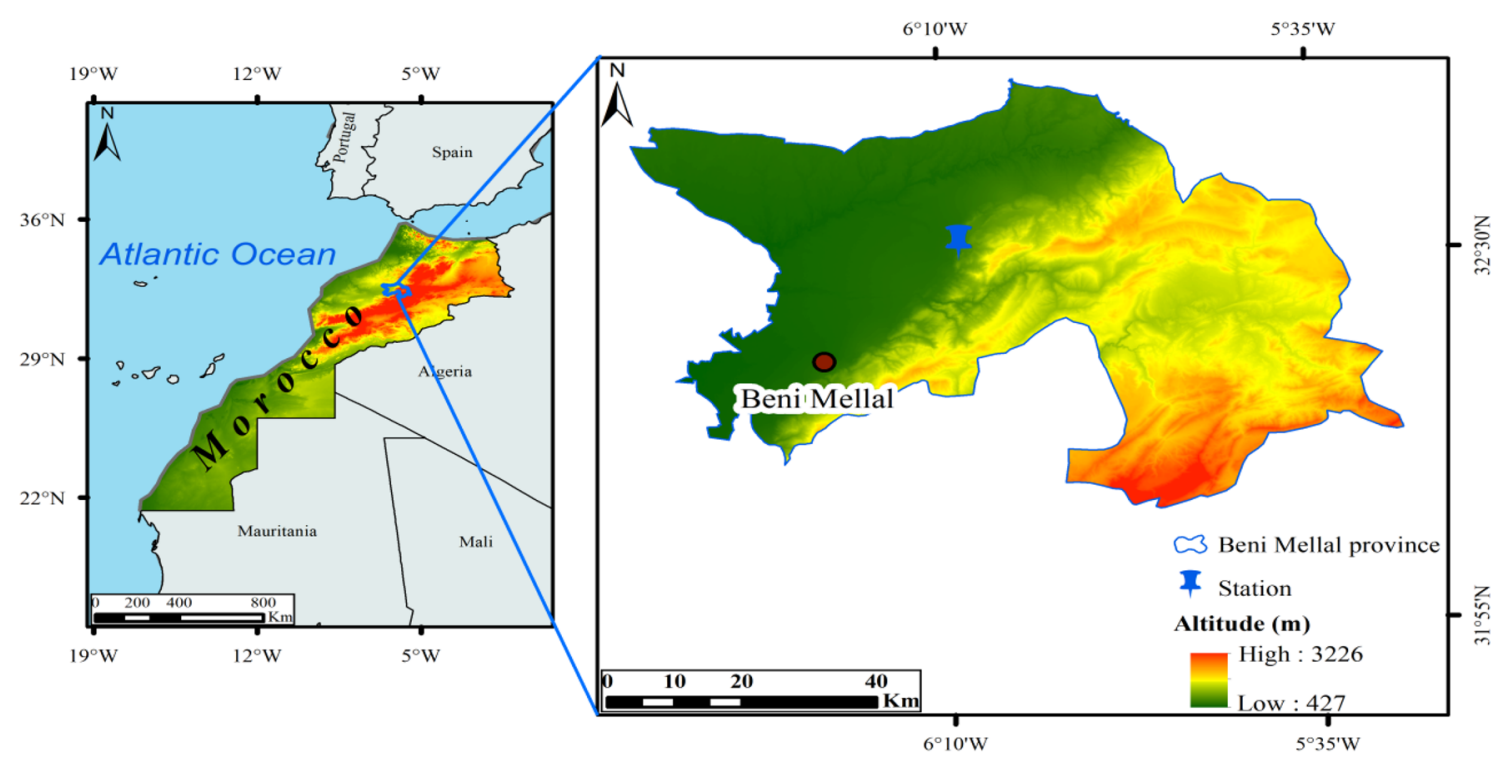

Fig. 1 Map of Beni Mellal area including the sampling station for the olive mill wastewater

Table 1 Characteristics of filtration sand

\begin{tabular}{ll}
\hline Size & $0.95 \mathrm{~mm}$ \\
Grains form & Rolled river \\
Acid loss & $<2 \%$ in weight \\
Density of grains & $>2.4$ \\
Quality & Non-friable material \\
Sand property & Washed sand \\
Percentage of pure silica & $>80 \%$ \\
Fire loss at $800{ }^{\circ} \mathrm{C}$ & $<1 \%$ \\
\hline
\end{tabular}

Table 2 Characteristics of granular activated carbon

\begin{tabular}{ll}
\hline Effective size & $0.8-1 \mathrm{~mm}$ \\
Ash content & $<13 \%$ \\
Acid soluble ash & $<8 \%$ \\
$\begin{array}{l}\text { Apparent density (backwash and } \\
\text { drained) }\end{array}$ & $475 \pm 25 \mathrm{~kg} / \mathrm{m}^{3}$ \\
Moisture (as packed) & $<5 \%$ \\
Uniformity coefficient & $<1.7$ \\
Origin & $\begin{array}{c}\text { Produced from bitumi- } \\
\text { nous coal by steam } \\
\text { activation }\end{array}$ \\
\hline
\end{tabular}

of filtration sand and granular activated carbon (AC) are presented in Tables 1 and 2, respectively.
Table 3 The content of each column

\begin{tabular}{ll}
\hline Column & Content \\
\hline T1 & Granular AC \\
T2 & Granular AC mixed with $5 \%$ of lime \\
T3 & Granular AC mixed with $10 \%$ of lime \\
T4 & Granular AC mixed with 15\% of lime \\
T5 & Filtration sand \\
T6 & Filtration sand mixed with $5 \%$ of lime \\
T7 & Filtration sand mixed with $10 \%$ of lime \\
T8 & Filtration sand mixed with $15 \%$ of lime \\
\hline
\end{tabular}

\subsection{Experimental procedure}

\subsubsection{Treatment by infiltration percolation}

Two successive treatments were used for treating olive mill wastewater, the first one is physicochemical by infiltration percolation using eight different columns, and the second is biological treatment by soil microorganisms under aerobic conditions. The experimental procedure for the first treatment consists of opaque eight PVC columns (8), $5 \mathrm{~cm}$ in diameter and $60 \mathrm{~cm}$ height. The PVC columns are filled with filtration sand, granular AC, filtration sand mixed with lime powder and granular AC mixed with lime powder as showed in Table 3. For the columns mixed with lime powder, $5 \mathrm{~cm}$ of filtration sand or granular AC in the top and the bottom of each column. The alimentation is the same for all columns. 


\subsubsection{Biological treatment}

For the biological treatment, it was realized in a reactor under aerobic conditions. The total volume treated is $1500 \mathrm{~mL}$ diluted 15 times with distilled water and neutralized with $\mathrm{H}_{2} \mathrm{SO}_{4}(0.1 \mathrm{~N})$.

\subsection{Soil sampling and microbiological soil analysis}

The used soil for treatment has been taken from the top layer $(10-30 \mathrm{~cm})$ of a clay texture parcel in the Beni Mellal area. The sample was collected into sterile bottles for microbiological analysis and transported immediately in thermos-cool boxes (at $4{ }^{\circ} \mathrm{C}$ ) with care in fast delays to the laboratory. The ideal is to work on fresh soil or stored in a refrigerator $\left(4^{\circ} \mathrm{C}\right)$. Drying of samples kills some of the microflora and makes it impossible to determine microbial biomass and also water stress can disrupt biological measurements [27]. The sample was then sieved to $5 \mathrm{~mm}$ in order to remove the rude elements and organic debris. Before use, the soil samples were sieved again to $2 \mathrm{~mm}$. The characteristics of soil used for biological treatment are presented in the following table (Table 4) [28]. The soil sample destined to microbiological analysis were taken in sterile flasks and transported immediately, using thermoscool boxes (at $4^{\circ} \mathrm{C}$ ) and in the dark to ensure permanent sample at a temperature between 0 and $4{ }^{\circ} \mathrm{C}$ in order to block the multiplication of bacteria already present in the soil.

The preparation is made from a suspension of $1 \mathrm{~g}$ of soil in $9 \mathrm{~mL}$ of peptone water. The suspension is subsequently stirred manually in order to release the maximum of the microbial load. Dilutions of soil sample studied were performed in peptone water and varied from $10^{-1}$ to $10^{-6}$. The isolation and enumeration of bacteria reflecting hygienic degrees such as Total Aerobic Flora, Total Coliforms, Fecal Coliforms, yeasts, and molds, were carried out according to international standards $[29,30]$.

\subsubsection{Bacteria enumeration}

The non-selective culture medium Plate Count Agar (PCA) was used for counting of Total Aerobic Flora (the incubation conditions were $72 \mathrm{~h}$ at $30^{\circ} \mathrm{C}$ ). Moreover, the Desoxycholate Lactose Agar (DLA, Oxoid, England), a selective

Table 4 Analysis results of soil quality indicators

\begin{tabular}{llllll}
\hline Soil depth & $\mathrm{pH}$ & $\begin{array}{l}\mathrm{CEC}(\mathrm{C} \mathrm{mol} / \\
\mathrm{kg})\end{array}$ & OC (\%) & $\begin{array}{l}\text { Clay and silt } \\
(\%)\end{array}$ & $\begin{array}{l}\text { Salinity } \\
(\mathrm{dS} / \mathrm{m})\end{array}$ \\
\hline $0-30 \mathrm{~cm}$ & 8.50 & 28.40 & 1.40 & 68.50 & 1.12 \\
\hline
\end{tabular}

CEC (C mol/kg) cation exchange capacity, OC (\%) organic carbon medium for the detection of Enterobacteriaceae was used for enumeration of coliforms (the incubation was operated during $48 \mathrm{~h}$ at $37^{\circ} \mathrm{C}$ for Total Coliforms and $44^{\circ} \mathrm{C}$ for Fecal Coliforms) [30].

\subsubsection{Enumeration of fungal flora}

For this aim, we incubated a selected sample in Potato Dextrose Agar Medium (PDA, Merck, England) during $72 \mathrm{~h}$ at $25^{\circ} \mathrm{C}$ for yeasts and 6-7 days for molds [30].

\subsubsection{Microbiological results}

The analysis of the microbiological results found for soil analysis used in this study showed that the soil utilized for the olive mill wastewater treatment was contaminated but at less level. Indeed, the enumeration of Fecal Coliforms (FC), Total Coliforms (TC) and Total Aerobic Flora (TAF), in soil sample from Beni Mellal region, showed average values of $4.2 \times 10^{3}, 3.25 \times 10^{4}, 1.75 \times 10^{6} \mathrm{UFC} / \mathrm{g}$ (per gram of soil), respectively for FC, TC and TAF. Moreover, the enumeration of Yeast and Molds showed the following values: $14 \times 10^{5}$ and $17 \times 10^{4} \mathrm{UFC} / \mathrm{g}$, respectively.

\subsection{Statistical analysis}

In the present work, data statistical treatments were performed by using the Microsoft Office Excel 2007, and Minitab 17 software packages.

Our analytical results were subjected to statistical analysis by one-way analysis of variance (ANOVA) $(a \leq 0.05)$ followed by the Tukey test for multiple-comparison using Minitab 17 software package.

\subsection{Infrared analysis}

Infrared spectra were registered using the apparatus PerkinElmer spectrum, Version 10.5.1 equipped with an attenuated total reflectance accessory with DTGS detector, Globar (MIR) Source and KBr Germanium separator. The acquisition conditions of the spectra are as follows: acquisition in attenuated total reflection, spectral range from $4000 \mathrm{~cm}^{-1}$ to $400 \mathrm{~cm}^{-1}$, resolution $4 \mathrm{~cm}^{-1}$, and 4 scan accumulations. The data were processed with the PerkinElmer software. 


\section{Results and discussion}

\subsection{Characterization of the olive mill wastewater used for treatment}

The characteristics of the investigated raw OMWW are summarized in Table 5. As can be seen from Table 5, the analysis results of the raw olive mill wastewater studied shows high values of all parameters measured and followed during this study. The raw OMWW has shown an acidic $\mathrm{pH}$ (4.81). The $\mathrm{pH}$ value recorded in our study is in the range (between 4.2 and 5.9) cited in the literature [31]. It has also a high electrical conductivity value $(E C=15.94$ $\mathrm{mS} / \mathrm{cm}$ ), this value reflects the high content of salts present in these effluents, which give it high values of electrical conductivity. Moreover, the pollutant load expressed in terms of chemical oxygen demand (COD) and biological oxygen demand $\left(\mathrm{BOD}_{5}\right)$ has been in the order of $227.33 \mathrm{~g} / \mathrm{L}$ and $46.4 \mathrm{~g} / \mathrm{L}$ respectively. The COD and $\mathrm{BOD}_{5}$ content are very high compared to that recorded in other types of rejects.

This shows the high oxygen demand for the complete oxidation of the organic matter contained in these effluents, which reflects their very high polluting powers. Thus, this $\mathrm{COD}$ and $\mathrm{BOD}_{5}$ contents in the OMWW investigated is very high compared to that recorded in other types of discharges, these values are 200-400 times higher than those of municipal wastewater [32]. Indeed, the COD does not exceed $4.02 \mathrm{~g} / \mathrm{L}$ in abattoir effluents, which are considered to be the main discharges of a dominant organic nature [33]. OMWW studied are very rich in suspended matter, their content is $29.25 \mathrm{~g} / \mathrm{L}$. These discharges are also characterized by the predominance of toxic substances, in particular, polyphenols $(11.41 \mathrm{~g} / \mathrm{L})$, explained by dark color of OMWW studied which gives them an antimicrobial effect [34]. The investigated OMWW has shown relatively high contents of phenolic compounds $(11.41 \mathrm{~g} / \mathrm{L})$, which has been significantly higher than the results cited by $[35,45]$ and which have been as values in the range of 1 and $3 \mathrm{~g} / \mathrm{L}$. In fact, OMWW phenolic compounds are the components that constitute the major origin of its effect and its toxicity $[36,37]$. The OMWW under study is highly loaded mainly in organic matter and phenolic compounds; it's the reason to treat this liquid wastewater that represents a liquid can damage environment systems. The following table, shows the chemical substances of both solid (olive pomace) and liquid by-products (olive mill wastewater) (Table 6).

\subsection{Treatment of raw olive mill wastewater by infiltration percolation in the column}

All treatments are realized with the same flow of raw olive mill wastewater. The global results are presented in Table 7.
Table 5 Olive mill wastewaters physicochemical characteristics

Table 6 Chemical composition of OMWW [38] and olive pomace [39]

\begin{tabular}{lllllll}
\hline Para meter & $\mathrm{pH}$ & $\mathrm{EC}(\mathrm{mS} / \mathrm{cm})$ & $\mathrm{SM}(\mathrm{g} / \mathrm{L})$ & $\mathrm{COD}(\mathrm{g} / \mathrm{L})$ & BOD $_{5}(\mathrm{~g} / \mathrm{L})$ & Polyphenols $(\mathrm{g} / \mathrm{L})$ \\
\hline Value & 4.81 & 16.79 & 29.25 & 227.33 & 46.40 & 11.41 \\
\hline
\end{tabular}

\begin{tabular}{lcll}
\hline Chemical composition of OMWW & Value $(\mathrm{g} / 100 \mathrm{~g})$ & $\begin{array}{l}\text { Chemical composition of } \\
\text { olive pomace }\end{array}$ & Fraction \\
\hline Water & $83-94$ & Crude protein & $5.2 \%$ \\
Organic compounds & $4-18$ & Crude fiber & $57.5 \%$ \\
Inorganic compounds & $0.4-2.5$ & Crude fat & $3.2 \%$ \\
Total solids & $3.2-30$ & Soluble carbohydrate & $20.7 \%$ \\
Fats and oils & $0.03-1.1$ & Ash & $13 \%$ \\
Sugars & $1-4.7$ & Lignin & $38.2 \%$ \\
Carbohydrates & $2-8$ & Calcium & $2.3 \%$ \\
Pectin & $1-1.5$ & Phosphorus & $0.3 \%$ \\
Phenolic compounds & $0.6-4.0$ & Potassium & $1.1 \mathrm{mg} / \mathrm{kg}$ \\
Nitrogen & $0.58-2$ & Magnesium & $10 \mathrm{mg} / \mathrm{kg}$ \\
Potassium & $0.3-0.9$ & Copper & $14.2 \mathrm{mg} / \mathrm{kg}$ \\
Phosphorus & $0.06-0.32$ & Zink & $97.2 \mathrm{mg} / \mathrm{kg}$ \\
Calcium & $0.32-0.53$ & & \\
Sodium & $0.04-0.48$ & & \\
Magnesium & $0.06-0.22$ & &
\end{tabular}


Table 7 Physicochemical characteristics of OMWW after infiltration percolation

\begin{tabular}{lrlcccc}
\hline OMWW type & pH & EC $(\mathrm{mS} / \mathrm{cm})$ & $\mathrm{SM}(\mathrm{g} / \mathrm{L})$ & $\mathrm{COD}(\mathrm{g} / \mathrm{L})$ & $\begin{array}{l}\text { Polyphenols } \\
(\mathrm{g} / \mathrm{L})\end{array}$ \\
\hline Raw OMWW & 4.81 & 16.79 & 29.95 & 227.33 & 11.41 & 46.4 \\
T1 & 6.40 & 18.57 & 2.34 & 150.72 & 8.48 & 37.85 \\
T2 & 6.95 & 18.78 & 3.09 & 132.48 & 6.67 & 33.80 \\
T3 & 8.91 & 19.23 & 3.10 & 110.00 & 5.55 & 30.00 \\
T4 & 9.13 & 19.27 & 3.37 & 90.29 & 5.34 & 28.15 \\
T5 & 6.14 & 17.42 & 3.14 & 170.16 & 9.64 & 41.55 \\
T6 & 7.92 & 18.19 & 3.61 & 160.6 & 8.16 & 37.25 \\
T7 & 9.20 & 19.20 & 4.29 & 147.19 & 6.79 & 35.84 \\
T8 & 10.90 & 21.60 & 4.87 & 134.78 & 5.98 & 35.15 \\
\hline
\end{tabular}

\subsubsection{Potential hydrogen, electrical conductivity and suspended matter}

The results obtained from the OMWW treatment by infiltration percolation in different columns are summarized in Table 7. These treatments were used for the first time to estimate the effectiveness of treatment by infiltration percolation using different columns of filtration sand and granular AC alone and mixed with different proportions of lime powder. The $\mathrm{pH}$ evolution shows an increase in $\mathrm{pH}$ value from an acidic $\mathrm{pH}(4.81)$ to $\mathrm{pH}$ near to neutrality when treatment of raw OMWW is realized only by filtration sand (6.14) or granular AC (6.40).

When the treatment performed by filtration sand or granular AC is mixed with different proportions of lime powder as showed in Table 3, the pH increases from acidic $\mathrm{pH} 4.81$ to alkaline $\mathrm{pH}$. A significant increase of OMWW pH has been observed with the increase of the doses added of lime. According to the $\mathrm{pH}$ values measured after the filtration of the OMWW through the different columns containing the different percentages of lime as shown in Table 3, the $\mathrm{pH}$ values increase with the increase of the added powdered lime to reach maximum values of 9.13 for the column of granular AC mixed with $15 \%$ of lime (T4), and 10.90 for the column of filtration sand mixed with $15 \%$ of lime (T8). The OMWW undergo different treatment processes during their passage through different columns used may be caused the ionic exchange in the columns and also the transformation of organic matter into mineral matter hence the achievement of an alkaline $\mathrm{pH}$. On the other hand, this increase in $\mathrm{pH}$ values with an increase in the proportion of lime is due to the alkaline power of the lime to obtain an alkaline $\mathrm{pH}$. In general $\mathrm{pH}$ evolution after all treatments are due to the increase in proportion of lime powder added. Consequently, the addition of lime to the column allowed the increase of the initial acidic $\mathrm{pH}$ (4.81) to an alkaline $\mathrm{pH}$ (superior to 7).

As shown in Table 7, the EC result of raw OMWW is 16.79 $\mathrm{mS} / \mathrm{cm}$, and after treatment by infiltration percolation, the
EC values for all OMWW obtained in different columns increased to achieve high values of $19.27 \mathrm{mS} / \mathrm{cm}$ and 21.60 $\mathrm{mS} / \mathrm{cm}$ for OMWW treated by granular AC column mixed with lime, and filtration sand column mixed with lime respectively. For sand or granular AC mixed with lime, the increase in electrical conductivity values is much greater, reflecting the richness of these effluents, after their infiltration in column, in dissolved ions and minerals, particularly those originating from lime $\left(\mathrm{Ca}^{2+}\right)$, this increase can also related to the leaching of sand minerals and the mineralization of organic matter.

The suspended matter is made up of fine particles. It's an index of pollution. It is formed by debris, minerals, organic and inorganic matter, therefore it can make liquid more turbid. The suspended matter is substantially reduced after infiltration percolation phenomenon through all columns (T1-T8). The SM decreases from $29.95 \mathrm{~g} / \mathrm{L}$ content in raw OMWW to a minimum value of $2.34 \mathrm{~g} / \mathrm{L}$ obtained for T1. As observed in Fig. 2, the removal efficiency of suspended matter obtained after infiltration percolation in all columns is high for columns of granular AC and filtration sand without adding lime. The addition of lime powder to each column as presented in Table 3 causes a weak decrease of SM content when the proportion of lime powder added

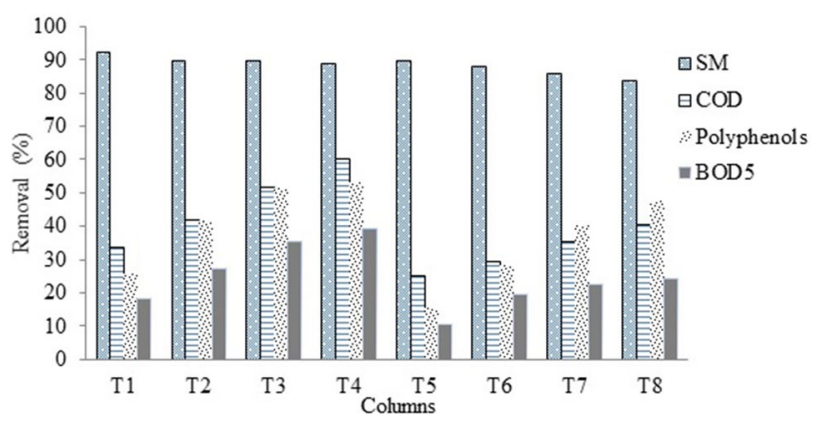

Fig. 2 Percent removal of suspended matter, $\mathrm{COD}, \mathrm{BOD}_{5}$, and polyphenols, at level of each column 
increases. The high removal percentages of suspended matter after infiltration percolation are explained by the fact that $A C$ and sand are wastewater filtration materials that can remove suspended matter by adsorption and filtration, due to their microporous structures. Thus, the efficiency of sand and granular AC in retaining particles is explained thus by the bonding of substances in OMWW to their surfaces and increases their size.

\subsubsection{Biological oxygen demand and chemical oxygen demand}

The analysis of OMWW after infiltration percolation showed that the biological oxygen demand content decreases notably after their passage through all columns. Figure 2 shows that the maximum attainable percentage removal of biological oxygen demand was around $39.33 \%$ at the T4 level, the minimum percentage removal of $\mathrm{BOD}_{5}$ is observed at $\mathrm{T} 5$ with $10.45 \%$ under the investigated experimental conditions, using different columns of filtration sand and granular AC without and with powder lime as represented in Table 3. The chemical oxygen demand (COD) presents an index for wastewater pollution, especially for OMWW. The analysis of COD concentration before and after treatment of OMWW through different columns indicates a significant reduction in all the columns, it decreases from 227.33 to $90.29 \mathrm{~g} / \mathrm{L}$ (T4). After infiltration percolation o raw olive mill wastewater, the reduction is generally varying between 25.15 and 60.28 for T5 and T4 respectively. As shown in Fig. 2 the percent removal increases when the proportion of powder lime increases at level of each column. The minimum values are observed in T1 and T5 whenever the treatment is realized without adding lime powder. The results showed a variable response depending on the type of material utilized in the treatment and on the quantities and proportions of the lime added.

The reduction in $\mathrm{COD}$ and $\mathrm{BOD}_{5}$ is mainly due to the adsorption of high molecular weight of organic molecules present in the olive mill wastewater on the surface of the sand and the granular AC during the infiltration percolation phenomenon on the different columns. The removal of $\mathrm{BOD}_{5}$ and $\mathrm{COD}$ content, which increases as the amount of lime increases, is thus achieved by the additional effect of lime by adsorption of organic matter on the surface of the lime particles during treatment in the presence of $\mathrm{Ca}(\mathrm{OH})_{2}$, which traps and absorbs the dissolved organic matter. This treatment procedure shows that lime powder is a factor giving amelioration to reduction of $\mathrm{BOD}_{5}$ and $\mathrm{COD}$.

\subsubsection{Polyphenols}

During the extraction process of olive oil, polyphenols concentration in olive is divided between the olive mill wastewater and the oil produced; nevertheless, the important fraction is missing in the liquid phase (OMWW) due to the fact that they are water-soluble substrates of high polarity [8]. The amount of polyphenols in the OMWW is ranges from 5 to $25 \mathrm{~g} / \mathrm{L}$ [9]. The black color is due to polyphenol compounds with high molecular weight persisted [40].

Table 7 shows the analysis of all parameters after and before treatment by infiltration percolation, the concentration of polyphenols decreases from one column to another and according to the proportion of lime added. The contents vary between the initial value of $11.41 \mathrm{~g} / \mathrm{L}$ (crude OMWW) and $5.34 \mathrm{~g} / \mathrm{L}$ obtained from T4. Figure 2 shows that the maximum attainable percentage of polyphenols removal was about $53.17 \%$ (T4) and the minimum percentage removal is observed at T5 with $15.43 \%$ under the investigated experimental conditions of each column as shown in Table 3. The concentration of polyphenols through each column decreases when the percentage of powder lime increases. These satisfactory results can be explained by the addition of lime for each column, and the latter causes higher adsorption and removal percentages of polyphenols on the surface of the substrate used in this step of treatment. Lime $(\mathrm{CaO})$ is often used for water treatment for its availability and effectiveness. In the other hand, their use for treatment leads to the transformation of phenols to phenates with the formation of $\mathrm{C}_{6} \mathrm{H}_{5} \mathrm{O}^{-}$ions [41]. These anions (phenates) formed in presence of lime during treatment can combine with the cations present in the columns and then the formation of large molecules that will adsorb to the surface of sand or granular AC, consequently the reduction of polyphenols compounds in the olive mill wastewater increases. The polyphenols obtained after treatment lose a large part of their antibacterial efficacy and biological activity can, therefore, be initiated [42]. It has been widely described that polyphenols are the main antibacterial compounds in the olive mill wastewater $[43,44]$. The infiltration percolation is very suitable for pretreatment as physicochemical step to treat and decrease the amount (content) of each physicochemical parameter.

The results of different treatments by infiltration percolation (Table 7) show that all this protocols give satisfactory reductions of all parameters studied, this removal efficiency of the different physicochemical parameters increase with the augmentation of lime powder amount added to each column to conclude that infiltration percolation using filtration sand mixed with lime and granular AC mixed with lime as pretreatment is an important and simple method has yielded significant results with low 
cost for treatment of this highly charged wastewater. In general, the results (Fig. 2) suggest that the high percentages removal of each parameter is directly related to the amount of lime added during treatment protocols.

The second step is to perform a biological treatment using soil microorganisms under aerobic conditions to the OMWW from the column that provided satisfactory results in terms of the abatement percentages (removal efficiency) of the different physicochemical parameters studied. To compare the effectiveness of different columns used in this part of study, and better understand the difference between the obtained results, we used the statistical analysis. After the single-variable ANOVA statistical analysis and the application of the Tukey test for $a \leq 0.05$ (Table 8), it is found that the treatment T4 yielded the best results as presented in Table 7 and leads to having the best reduction of the different measured parameters. The obtained olive mill wastewater treated by column 4 (T4) was subjected to the next step that is the biological treatment by the soil microorganisms.

\subsection{Global results of each physicochemical parameter with time during biological treatment}

The biological treatment of olive mill wastewater from T4 was performed 30 days under aerobic conditions by following the changes of some physicochemical parameters. Before starting treatment, the olive mill wastewater under study is diluted 15 times with distilled water and neutralized with $\mathrm{H}_{2} \mathrm{SO}_{4}$. Several reports indicated that dilution of olive mill wastewater was essential to reduce the initial organic load and the polyphenols prior to biological treatment to facilitate the organic matter degradation [45]. El Hajjouji et al. [46] have shown that during biological treatment of olive mill wastewater, $\mathrm{pH}$ correction may be necessary, it favored microbial activity and hence the degradation of polyphenols and also of other compounds, for this reason, the dilution and neutralization are required, the latter is performed. Due to the low or high $\mathrm{pH}$ values, biological treatment of OMWW is limited by the need for micro-organisms able to grow at acidic or high alkaline $\mathrm{pH}$. The monitoring of the physicochemical parameters studied was done every 4 days and the results after 30 days are presented in Table 9. The percentage reduction as a function of time of each three physicochemical parameters is summarized in Fig. 3.

Results have shown that the biological treatment of olive mill wastewater by soil microorganisms has induced a clear increase in the $\mathrm{pH}$ and electrical conductivity values and a decrease of the other chemical parameters. Potential hydrogen $(\mathrm{pH})$ of the OMWW before treatment was neutral (7.04) but during the treatment its value increases over time to a final value of 9.14 recorded after the treatment time which is 30 days. The almost similar results are obtained by Hamdi et al. [47], who also noted an increase in $\mathrm{pH}$ during the biodegradation of organic matter in OMWW by soil microorganisms. The increase in $\mathrm{pH}$ values

Table 9 Global results obtained during biological treatment

\begin{tabular}{llllll}
\hline $\begin{array}{l}\text { Treatment } \\
\text { time (days) }\end{array}$ & $\mathrm{pH}$ & $\mathrm{EC}(\mu \mathrm{S} / \mathrm{cm})$ & $\mathrm{BOD}_{5}(\mathrm{~g} / \mathrm{L})$ & $\mathrm{COD}(\mathrm{g} / \mathrm{L})$ & $\begin{array}{l}\text { Polyphe- } \\
\text { nols }(\mathrm{g} / \mathrm{L})\end{array}$ \\
\hline 0 & 7.04 & 1075 & 28.15 & 90.29 & 5.34 \\
4 & 7.73 & 1694 & 25.75 & 63.5 & 4.16 \\
8 & 8.27 & 1713 & 21.45 & 53.4 & 3.84 \\
12 & 8.51 & 1765 & 20.74 & 45.1 & 3.14 \\
16 & 8.80 & 1831 & 14.77 & 40.2 & 2.89 \\
20 & 8.87 & 1884 & 9.15 & 37.2 & 2.76 \\
24 & 9.01 & 1911 & 6.67 & 30.6 & 2.25 \\
30 & 9.14 & 1938 & 5.85 & 27.6 & 2.10 \\
\hline
\end{tabular}

Table 8 Statistical analysis of the obtained results after infiltration percolation

\begin{tabular}{lllll}
\hline Column & \multicolumn{4}{l}{ Removal efficiency (\%) } \\
\cline { 2 - 5 } & SM & COD & Polyphenols & BOD $_{5}$ \\
\hline T1 & $92.19 \pm 0.31^{\mathrm{A}}$ & $33.70 \pm 1.70^{\mathrm{DE}}$ & $25.65 \pm 1.80^{\mathrm{D}}$ & $18.43 \pm 0.62^{\mathrm{D}}$ \\
$\mathrm{T} 2$ & $89.68 \pm 0.62^{\mathrm{AB}}$ & $41.72 \pm 0.22^{\mathrm{C}}$ & $41.50 \pm 0.55^{\mathrm{BC}}$ & $27.15 \pm 2.18^{\mathrm{B}}$ \\
T3 & $89.63 \pm 0.58^{\mathrm{AB}}$ & $51.61 \pm 0.02^{\mathrm{B}}$ & $51.30 \pm 0.57^{\mathrm{A}}$ & $35.34 \pm 0.89^{\mathrm{A}}$ \\
T4 & $88.74 \pm 0.67^{\mathrm{BC}}$ & $60.28 \pm 1.86^{\mathrm{A}}$ & $53.17 \pm 1.56^{\mathrm{A}}$ & $39.33 \pm 1.32^{\mathrm{A}}$ \\
T5 & $89.51 \pm 0.91^{\mathrm{AB}}$ & $25.15 \pm 1.97^{\mathrm{F}}$ & $15.43 \pm 1.86^{\mathrm{E}}$ & $10.45 \pm 1.58^{\mathrm{E}}$ \\
T6 & $87.95 \pm 0.80^{\mathrm{BC}}$ & $29.32 \pm 1.57^{\mathrm{EF}}$ & $28.51 \pm 1.41^{\mathrm{D}}$ & $19.72 \pm 0.03^{\mathrm{CD}}$ \\
T7 & $85.69 \pm 0.36^{\mathrm{CD}}$ & $35.25 \pm 0.52^{\mathrm{D}}$ & $40.42 \pm 1.46^{\mathrm{C}}$ & $22.74 \pm 1.47^{\mathrm{BCD}}$ \\
T8 & $83.72 \pm 1.46^{\mathrm{D}}$ & $40.71 \pm 1.22^{\mathrm{C}}$ & $47.55 \pm 2.51^{\mathrm{AB}}$ & $24.24 \pm 1.46^{\mathrm{BC}}$ \\
$P$ value & 0.000 & 0.000 & 0.000 & 0.000 \\
Standard error & 0.79 & 1.34 & 1.58 & 1.34 \\
\hline
\end{tabular}

Different letters in the same column indicate significant differences at Tukey test. The letter A corresponds to the highest value 


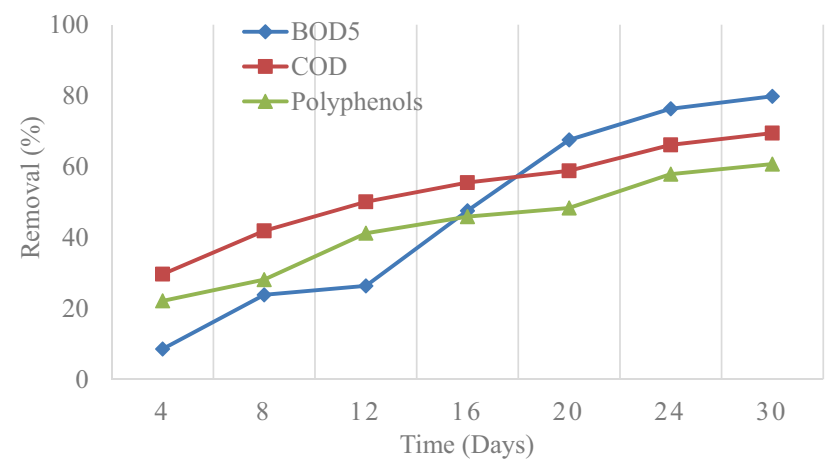

Fig. 3 Percent removal of $\mathrm{COD}, \mathrm{BOD}_{5}$, and polyphenols during biological treatment

during treatment may be attributed in part to the high reduction in polyphenols contents and relatively moderate reductions in organic matter (as showed by lower COD concentrations) of which organic acids were considered to be major components [48]. Electrical conductivity is closely related to the concentration of dissolved substances and their nature. In the case of raw OMWW, the values of this conductivity vary between 18 and $50 \mathrm{mS} / \mathrm{cm}$ [49]. In our case of biological treatment, we can see that the EC values increase with the increase in treatment time; this can be explained by the transformation of the organic matter into mineral matter and therefore the increase in the EC values. This transformation is carried out by the degradation of organic matter into mineral matter by soil microorganisms and thus the increase in electrical conductivity. It reflects the amount of mineral matter present in the solution under treatment.

Figure 3 represents the results obtained as a percentage reduction of three parameters such as $\mathrm{BOD}_{5}, \mathrm{COD}$, and polyphenols as a function of time. The results show that only after 4 days of treatment the removal efficiency of each parameter are $8.53,22.10$ and $29.67 \%$ for $\mathrm{BOD}_{5}$, polyphenols, and COD respectively, and when the treatment time increases and after 20 days the percentage reduction of $\mathrm{BOD}_{5}$ reached higher values than at the beginning of treatment and more than the other parameters to reach a final value of $79.78 \%$ higher than 69.43 and $60.67 \%$ obtained for COD and polyphenols respectively after 30 days of treatment.

In conditions of neutral $\mathrm{pH}$, phenols become transformed into phenates, reducing and losing part of their antimicrobial activity and become suitable for use as a carbon source for microbial activity [50], and facilitating their metabolization by microorganisms. Also, the drop in COD, $\mathrm{BOD}_{5}$, and polyphenols resulted from the degradation of organic matter by the microorganisms which use the carbon as an energy source during treatment processes [50, 51].
The neutralization of the $\mathrm{pH}$ has a positive effect on the degradation of phenols and organic matter by microorganisms, with a drop that reached about $79.78,69.43$ and $60.67 \%$ for $\mathrm{BOD}_{5}, \mathrm{COD}$, and polyphenols respectively. The abatement of phenolic compounds would be related to the greatest activity of the aerobic microorganisms of the soil which seems to be responsible for the degradation of the phenolic compounds in this step of olive mill wastewater treatment. These elevated amounts of organic matter and polyphenols degradation may be due to the impact of aeration.

Spectra of olive mill wastewater at different stages of treatment are used in this work to illustrate and show the effectiveness of each treatment and confirm our obtained analytical results of each treatment step of this black wastewater. The primary role of Fourier Transformed Infrared Spectroscopy (FTIR) uses being to assist in the identification and structural elucidation of organic compounds. The mid-infrared (MIR) spectrum examination of the raw OMWW is clearly indicating a number of bands on the spectrum (Fig. 4a). The analysis showed a large and intense band at $3280 \mathrm{~cm}^{-1}$ which represents the observed $\mathrm{O}-\mathrm{H}$ [52] elongation for phenols, alcohols and carboxylic groups. The band located at about $2918 \mathrm{~cm}^{-1}$ with lower intensity is assigned to $\mathrm{C}-\mathrm{H}$ stretching vibration in aliphatic structures (fatty acids, waxes, and various aliphatics). At almost $1744 \mathrm{~cm}^{-1}$ there is a weak band characteristic for $\mathrm{C}=\mathrm{O}$ stretching vibrations in esters, carboxyl $\mathrm{COOH}$, and ketone groups. At $1540-1570 \mathrm{~cm}^{-1}$ there is an $\mathrm{N}-\mathrm{H}$ vibrations deformation in secondary amides. The band around $1382 \mathrm{~cm}^{-1}$, is due to symmetrical $-\mathrm{CH}_{3}$ stretching vibrations. The bands at $900-1300 \mathrm{~cm}^{-1}$ represents vibrations of $\mathrm{C}-\mathrm{H}$ and deformation of $\mathrm{OH}$ functions, carboxyls, $\mathrm{C}-\mathrm{O}$ of ethers on aromatic rings and $\mathrm{N}-\mathrm{H}$ of secondary amides. These two other spectra (Fig. 4b, c) were obtained after different steps during treatment processes; first one (spectrum b) after infiltration percolation (T4) and the second spectrum is performed after biological treatment (Fig. 4c).

According to the infrared spectra of the OMWW after each treatment, it well seen that almost the same bands for all spectra with nearly disappearing of some small bands but with different intensities, the relative intensity of all bands decreases from one treatment to another, it showed by the reduction in all peak (band) intensity (decrease in the concentration of the compounds forming olive mill wastewater after each treatment step). Fourier Transformed Infrared spectroscopy showed the differences in intensity between the spectrum of the raw OMWW and that obtained after infiltration percolation (T4) and after biological treatment. It can be concluded that the FTIR, is a fast method that can confirm our analytical results in terms of percentage reductions in physicochemical parameters 


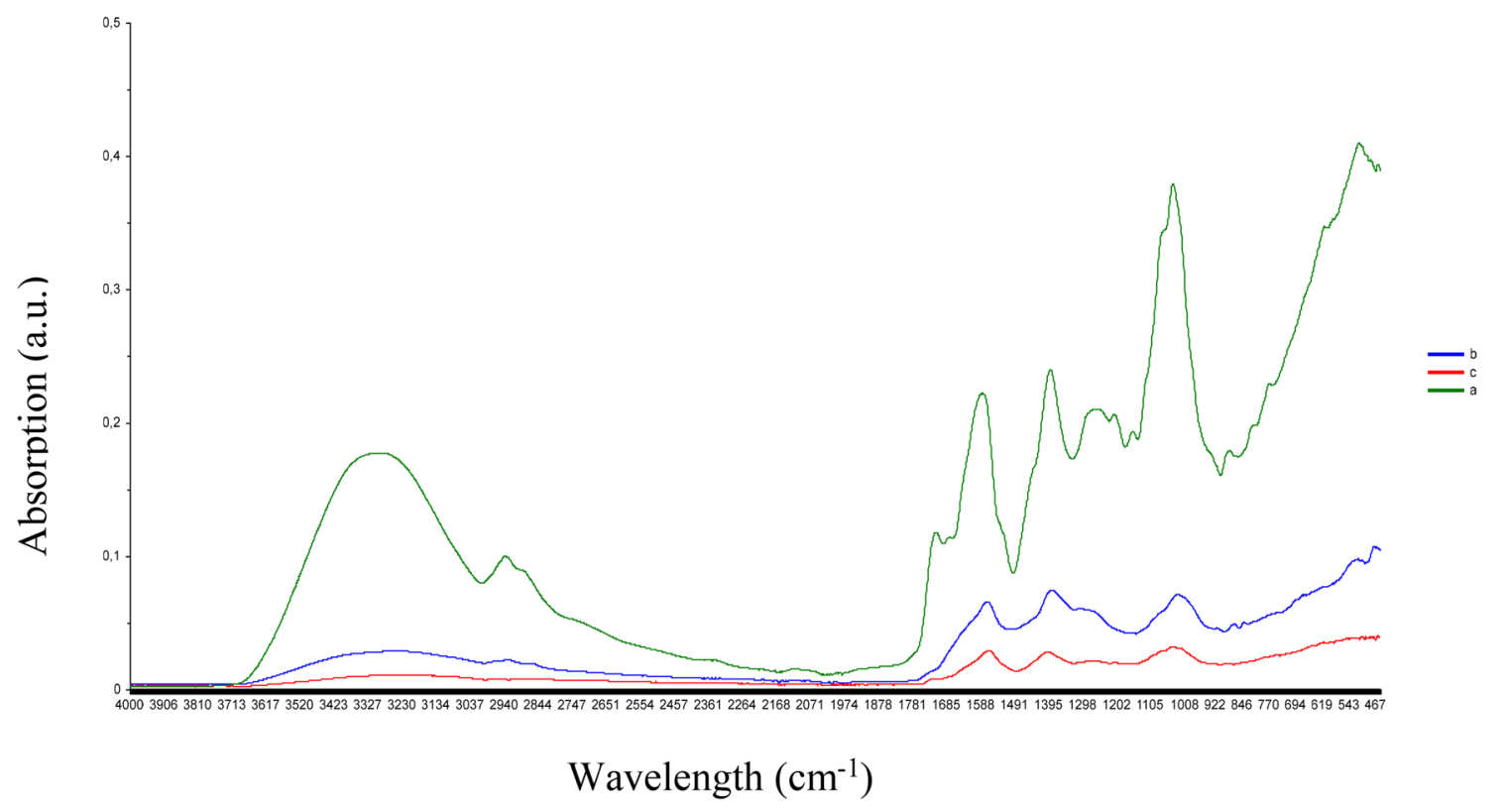

Fig. 4 FTIR-ATR spectra of powdered OMWW samples for raw OMWW (a), from T4 (b) and after biological treatment (c)

studied and show the differences between spectra from one treatment to another.

The total reduction of the parameters after the two successive treatments achieved an important drop with 87.86, 87.39 and $81.59 \%$ for $\mathrm{COD}, \mathrm{BOD}_{5}$, and polyphenols respectively. These results obtained showed that the main quality parameters of olive mill wastewater decreased instantaneously after each treatment. In this sense, our work demonstrates the important role of infiltration percolation treatment and biological treatment combination to remove organic matter and phenolic compounds responsible for pollution and toxicity of olive mill wastewater.

From Table 10, which shows the comparison of the effeciency of our method used in this work with another method used by Najjar et al. [53], the results show that our process gives the best removal percentage for the different parameters, which makes the proposed method effective and simple for olive mill wastewater treatment.

\section{Conclusions}

The olive mill wastewater from the olive oil producing industries is a major problem especially for the countries of the Mediterranean basin because they contain a significant organic fraction and cause several types of pollution. The results obtained after treatment by infiltration percolation in all columns showed significant reductions for all various parameters at level of all columns as well as an increase in $\mathrm{pH}$ and electrical conductivity with maximum removal of all parameters observed for T4 column. Biological treatment with soil microorganisms under aerobic conditions was applied to OMWW from column T4. The results showed an increase in the percentage removal of each physicochemical parameter followed over time up to values of $79.78,69.43$ and $60.67 \%$ for $\mathrm{BOD}_{5}, \mathrm{COD}$, and polyphenols respectively after 30 days of treatment. Moreover, the final pH of treated OMWW was 9.14. The total removal

Table 10 Comparison of proposed method with other methods

\begin{tabular}{|c|c|c|c|}
\hline Origin of OMWW & Treatment process & Scale & Achieved pourcentage removal \\
\hline Traditional process & $\begin{array}{l}\text { Wet hydrogen peroxide catalytic oxidation (WHPCO) with Fe-BEA zeolite- } \\
\text { based catalysts }\end{array}$ & Lab-scale & $\begin{array}{l}\text { Removal efficiencies of TOC } \\
\text { (total organic carbon), total } \\
\text { phenols and COD equal to 28, } \\
40 \text { and } 30 \%\end{array}$ \\
\hline Traditional process & $\begin{array}{l}\text { Infiltration percolation in column followed by aerobic biological treat- } \\
\text { ment }\end{array}$ & Lab-scale & $\begin{array}{l}\text { Removal efficiencies of COD, } \\
\text { BOD }_{5} \text { and phenolic com- } \\
\text { pounds equal to } 87.86,87.39 \\
\text { and } 81.59 \%\end{array}$ \\
\hline
\end{tabular}


efficiency of the physicochemical parameters after the two successive treatments achieved a high drop with $87.86,87.39$ and $81.59 \%$ for $C O D$, BOD $_{5}$, and polyphenols respectively. Besides Fourier Transformed Infrared analysis (FT-IR) of raw OMWW, T4 and biological treatment indicated a decrease in band intensity after each treatment, confirming our analytical results represented by reduction in each parameter. The results indicated that the treatment of OMWW by infiltration percolation in column followed by biological treatment is a process that reduced the environmental impact of OMWW. The combination of these two successive treatments has given a satisfactory total reduction by reducing the organic matter and polyphenols concentration as well as toxicity to reuse in irrigation without damage to environmental systems. The present work showed that the infiltration percolation in column followed by biological treatment represents an important and simple solution for treatment of these effluents that can pollute and damage the various components of the environment.

\section{Compliance with ethical standards}

Conflict of interest The authors declare that they have no competing interests.

\section{References}

1. Meftah O, Guergueb Z, Braham M, Sayadi S, Mekki A (2019) Long term effects of olive mill wastewaters application on soil properties and phenolic compounds migration under arid climate. Agric Water Manag 212:119-125

2. El Yamani M, Sakar EH, Boussakouran A, Ghabbour N, Rharrabti $Y$ (2019) Physicochemical and microbiological characterization of olive mill wastewater (OMW) from different regions of northern Morocco. J Environ Technol. https://doi. org/10.1080/09593330.2019.1597926

3. Annab H, Fiol N, Villaescusa I, Essamri A (2018) A proposal for the sustainable treatment and valorisation of olive mill wastes. J Environ Chem Eng. https://doi.org/10.1016/j. jece.2018.11.047

4. Gernjak W, Maldonado MI, Malato S, Cáceres J, Krutzler T, Glaser A, Bauer R (2004) Pilot-plant treatment of olive mill wastewater (OMWW) by solar TiO photocatalysis and solar photo-Fenton. Sol Energy 77:567-572

5. Rinaldi M, Rana G, Introna M (2003) Olive-mill wastewater spreading in southern Italy: effects on a durum wheat crop. Field Crops Res 84:319-326

6. Pérez J, De La Rubia T, Ben Hamman O, Martinez J (1998) Phanerochaete flavidoalba laccase induction and modification of manganese isoenzyme pattern in decolorized olive oil mill wastewaters. J Appl Environ Microbiol 27:26-29

7. Magdich S, Ben Ahmed C, Jarboui R, Ben Rouina B, Boukhris $M$, Ammar E (2013) Dose and frequency dependent effects of olive mill wastewater treatment on the chemical and microbial properties of soil. Chemosphere 93:1896-1903
8. Rodis PS, Karathanos VT, Mantzavinou A (2002) Partitioning of olive oil antioxidants between oil and water phases. J Agric Food Chem 50:596-601

9. Yangui A, Abderrabba M (2018) Towards a high yield recovery of polyphenols from olive mill wastewater on activated carbon coated with milk proteins: experimental design and antioxidant activity. Food Chem 262:102-109

10. Danellakis D, Ntaikou I, Kornaros M, Dailianis S (2011) Olive oil mill wastewater toxicity in the marine environment: alterations of stress indices in tissues of mussel Mytilus galloprovincialis. Aquat Toxicol 101:358-366

11. Ntougias S, Gaitis F, Katsaris P, Skoulika S, Iliopoulos N, Zervakis GI (2013) The effects of olives harvest period and production year on olive mill wastewater properties - evaluation of Pleurotus strains as bioindicators of the effluent's toxicity. Chemosphere 92:399-405

12. Lee SP, Ali GAM, Algarni H, Chong KF (2019) Flake sizedependent adsorption of graphene oxide aerogel. J Mol Liq 277:175-180

13. Sadegh $\mathrm{H}$, Ali GAM, Makhlouf ASH, Chong KF, Alharbi NS, Agarwal S, Gupta VK (2018) MWCNTs- $\mathrm{Fe}_{3} \mathrm{O}_{4}$ nanocomposite for $\mathrm{Hg}$ (II) high adsorption efficiency. J Mol Liq 258:345-353

14. Habeeb OA, Ramesh K, Ali GAM, Yunus RM (2017) Low-cost and eco-friendly activated carbon from modified palm kernel shell for hydrogen sulfide removal from wastewater: adsorption and kinetic studies. Desalin Water Treat 84:205-214

15. Alshehri SM, Naushad M, Ahamad T, Alothman ZA, Aldalbahi A (2014) Synthesis, characterization of curcumin based ecofriendly antimicrobial bio-adsorbent for the removal of phenol from aqueous medium. Chem Eng Technol 254:181-189

16. Hodaifa G, Gallardo PAR, García CA, Kowalska M, Seyedsalehi $M$ (2019) Chemical oxidation methods for treatment of real industrial olive oil mill wastewater. J Taiwan Inst Chem E 97:247-254

17. Paraskeva P, Diamadopoulos E (2006) Technologies for olive mill wastewater (OMWW) treatment: a review. J Chem Technol Biotechnol 81:475-485

18. Bouranis DL, Vlyssides AG, Drossopoulos JB, Karvouni G (1995) Some characteristics of a new organic soil conditioner from the co-composting of olive oil processing wastewater and solid residue. Commun Soil Sci Plant Anal 26:2461-2472

19. Al-Malah K, Azzam MOJ, Abu-Lail NI (2000) Olive mills effluent (OME) wastewater post-treatment using activated clay. Sep Purif Technol 20:225-234

20. Martínez Nieto L, Hodaifa G, Rodríguez Vives JA, Giménez Casares J, Ochando J (2011) Flocculation-sedimentation combined with chemical oxidation process. Water 39(10):949-955

21. Tezcan Ün Ü, Ugur S, Koparal AS, Ögütveren ÜB (2006) Electrocoagulation of olive mill wastewaters. Sep Purif Technol 52:136-141

22. Hodaifa G, Ochando-Pulido JM, Rodriguez-Vives S, MartinezFerez A (2013) Optimization of continuous reactor at pilot scale for olive-oil mill wastewater treatment by Fenton-like process. Chem Eng J 220:117-124

23. Scoma A, Bertin L, Zanaroli G, Fraraccio S, Fava F (2011) A physicochemical-biotechnological approach for an integrated valorization of olive mill wastewater. Bioresour Technol 102:10273-10279

24. Rejesek F (2001) Analyse des eaux: aspect réglementaires et techniques, Sciences et techniques de l'environnement. CRDP d'aquitaine, Bordeaux

25. Rodier J (1996) Analyse de l'eau : eaux naturelles, eaux résiduaires, eaux de mer. 8 éme édition, Dunod

26. Atanassovaa D, Kefalasa P, Psillakisb E (2005) Measuring the antioxidant activity of olive oil mill wastewater using chemiluminescence. Environ Int 31:275-280 
27. Fardoux J, Fernandes P, Niane-Badiane A, Chotte JL (2000) Effet du séchage d'échantillons d'un sol ferrugineux tropical sur la détermination de la biomasse microbienne: comparaison de deux méthodes biocidales de référence. Etude et gestion des sols 7:385-394

28. Ennaji W, Barakat A, El Baghdadi M, Oumenskou H, Aadraoui M, Karroum LA, Hilali A (2018) GIS-based multi-criteria land suitability analysis for sustainable agriculture in the northeast area of Tadla plain (Morocco). J Earth Syst Sci 127:1-14

29. International Commission on Microbiological Specifications for Foods (ICMSF) (1986) Microorganisms in foods 2. sampling for microbiological analysis: principles and specific applications, 2nd edn. University Toronto Press, Canada

30. Hnini R, Ouhida L, Chigr M, Merzouki M, Bahi L, El Hansali M, Najimi M, Chigr F (2018) Evalution of the microbiological quality of moroccan cow raw milk in dairy herds located in the Beni Mellal Region. World J Res Rev 7:19-23

31. Eroğlu E, Eroğlu I, Gündüz U, Yücel M (2008) Effect of clay pretreatment on photo fermentative hydrogen production from olive mill wastewater. Bioresour Technol 99:6799-6808

32. Tabet D, Saidi M, Houari M, Pichat P, Khalaf H (2006) Fe-pillared clay as a Fenton-type heterogeneous catalyst for cinnamic acid degradation. J Environ Manage 80:342-346

33. Aissa H, Penninckx M, Benlemlih M (2007) Reduction of phenolics content and COD in olive oil mill wastewaters by indigenous yeasts and fungi. World J Microbiol Biotechnol 23:1203-1208

34. Capasso R, Evidente A, Schivo L, Orru G, Marcialis MA, Cristinzio G (1995) Antibacterial polyphenols from olive oil mill waste waters. J Appl Bacteriol 79:393-398

35. Bargougui L, Guergueb Z, Chaieb M, Braham M, Mekki A (2019) Agro-physiological and biochemical responses of Sorghum bicolor in soil amended by olive mill wastewater. Agric Water Manag 212:60-67

36. Mekki A, Dhouib A, Feki F, Sayadi S (2013) Review: effects of olive mill wastewater application on soil properties and plants growth. J Recycl Org Waste Agric 2:15

37. Chaari L, Elloumi N, Mmseddi S, Gargougri K, Rouina BB, Mechichi T, Kallel M (2014) Effects of olive mill wastewater on soil nutrients availability. Int J Interdiscip Multidiscip Stud 2:175-183

38. Galanakis CM (2018) Phenols recovered from olive mill wastewater as additives in meat products. Trends Food Sci Technol 79:98-105

39. Matarneh ME (2016) Enhancement of steel A308 hardness utilizing olive Pomace. Procedia Eng 165:1468-1477

40. Hamdi M, Garcia JL, Ellouz R (1992) Integrated biological process for olive mill wastewater treatment. Bioprocess Eng 8:79-84

41. Macheix JJ, Fleuriet A, Billot J (1990) Fruit phenolics. CRC Press Inc, Boca Raton Florida
42. Yaakoubi $A$, Chahlaoui $A$, Rahmani M, Elyachioui M, Oulhote $Y$ (2010) Effet de l'épandage des margines sur la microflore du sol. Agro Solut 20:35-43

43. Thielmann J, Kohnen S, Hauser C (2017) Antimicrobial activity of Olea europaea Linné extracts and their applicability as natural food preservative agents. Int J Food Microbiol 251:48-66

44. Yangui T, Sayadi S, Rhouma A, Dhouib A (2010) Potential use of hydroxytyrosol-rich extract from olive mill wastewater as a biological fungicide against Botrytis cinerea in tomato. J Pest Sci 83:437-445

45. Daâssi D, Belbahri L, Vallat A, Woodward S, Nasri M, Mechichi T (2014) Enhanced reduction of phenol content and toxicity in olive mill wastewaters by a newly isolated strain of Coriolopsis gallica. Environ Sci Pollut Res Int 21:1746-1758

46. El Hajjouji H, Ait Baddi G, Yaacoubi A, Hamdi H, Winterton $P$, Revel JC, Hafidi M (2008) Optimisation of biodegradation conditions for the treatment of olive mill wastewater. Bioresour Technol 99:5505-5510

47. Hamdi M, Festino C, Aubart C (1992) Anaerobic digestion of olive mill wastewaters in fully mixed film reactors and in fixed film reactors. Process Biochem 27:37-42

48. Bazzarelli F, Piacentini E, Poerio T, Mazzei R, Cassano A, Giorno L (2016) Advances in membrane operations for water purification and biophenols recovery/valorization from OMWWs. J Memb Sci 497:402-409

49. Di Serio MG, Lanza B, Mucciarella MR, Russi F, lannucci E, Marfisi P, Madeo A (2008) Effects of olive mill wastewater spreading on the physico-chemical and microbiological characteristics of soil. Int Biodeter Biodegr 62:403-407

50. Borja R, Martin A, Alonso V, Garcia I, Banks CJ (1995) Influence of different aerobic pretreatments on the kinetics of anaerobic digestion of olive mill wastewater. Water Res 29:489-495

51. Hafidi M, Amir S, Revel JC (2005) Structural characterization of olive mill waste-water after aerobic digestion using elemental analysis, FTIR and ${ }^{13} \mathrm{C}$ NMR. Proc Biochem 40:2615-2622

52. Ali GAM, Makhlouf SA, Yusoff MM, Chong KF (2015) Structural and electrochemical characteristics of graphene nanosheets as supercapacitor electrodes. Rev Adv Mater Sci 40:35-43

53. Najjar W, Azabou S, Sayadi S, Ghorbel A (2009) Screening of Fe-BEA catalysts for wet hydrogen peroxide oxidation of crude olive mill wastewater under mild conditions. Appl Catal B Environ 88:299-304

Publisher's Note Springer Nature remains neutral with regard to jurisdictional claims in published maps and institutional affiliations. 